\title{
Seasonal changes in stable carbon and nitrogen isotope compositions of bat guano (Guadeloupe)
}

Aurélien Royer a,?], Alain Queffelec ${ }^{\mathrm{a}}$, Karine Charlier ${ }^{\mathrm{b}}$, Elysandre Puech ${ }^{\mathrm{a}}$, Bruno Malaizé ${ }^{\mathrm{b}}$, Arnaud Lenoble $^{\text {a }}$

a'Université de Bordeaux, PACEA UMR CNRS 5199, Allée Geoffroy St Hilaire, CS 50 023, 33615 Pessac, France

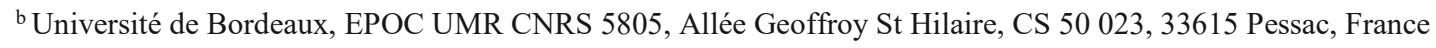

\section{Abstract}

Stable isotope compositions of fossil bat guano have recently been developed as a proxy for reconstructing terrestrial paleoenvironments. However, our understanding of exactly how accurately these isotope compositions reflect seasonal variations remains limited. Here, we present a study of modern guano of phytophagous bats collected monthly over a one-year period at two roosting sites in Guadeloupe. The aim is to assess the degree to which seasonal climate and environmental variations are reflected in carbon and nitrogen isotope compositions from bat guano, as well as to evaluate the potential use of guano from phytophagous bats as a paleoenvironmental record. Our results show that stable isotope compositions vary locally, suggesting that guano of phytophagous bats accurately records local environmental conditions. Additionally, stable isotope compositions reflect seasonal variations influencing bat diet that lead to modifications of up to $2 \%$ of the carbon isotope compositions from feces. However, these variations are not correlated solely with climate variables as there is no straightforward relationship between climate, vegetation and bat diet over a one-year period. Moreover, these seasonal variations drive one of the bat colonies to occasionally consume insects, which can be traced as a seasonal shift in $\% \mathrm{~N}$ (up to $4.5 \%$ ) and carbon isotope compositions (up to 5.6\%). Seasonal changes in isotope compositions are still lower than expected variations from fossil feces, confirming the potential use of feces from phytophagous bats as a reliable paleoenvironmental proxy.

Keywords: Guano ; Carbon isotope compositions ; Nitrogen isotope compositions ; Climate ; Seasonal variations

\section{Introduction}

Over the last fifty years, numerous climate proxies have been developed for reconstructing continental paleoclimate and paleoecological conditions based on different data sources, including lacustrine deposits (e.g. Hodell et al., 1991, 2008; Bertran et al., 2004; Stansell et al., 2010; Malaizé et al., 2011), speleothems (e.g. Lachniet et al., 2004, 2009; Fensterer et al., 2013), faunal remains (e.g. Pregill and Olson, 1981; Olson, 1982; Emery and Kennedy Thornton, 2008) or fecal deposits (e.g. Chase et al., 2012). Guano deposits constitute valuable millennialscale terrestrial paleoenvironmental records, derived from either palynological data (Carrión et al., 2006; Maher, 2006; Geantă et al., 2012) or stable isotope compositions (Des Marais et al., 1980; Wurster et al., 2010b). The abundance of laminated guano in Quaternary deposits potentially provide a high resolution record of continental climate change, notably in subtropical and tropical areas, where these types of deposit are most abundant (Mizutani et al., 1992a,b; McFarlane et al., 2002; Wurster et al., 2008, 2010a). 
In addition to reconstructing paleoenvironments, stable isotope compositions of carbon and nitrogen $\left(\delta^{13} \mathrm{C}\right.$ and $\left.\delta^{15} \mathrm{~N}\right)$ are commonly used to study terrestrial animal ecology (e.g. Fleming et al., 1993; Herrera et al., 1993; Hobson, 1999; Popa-Lisseanu et al., 2015) given that (a) specific dietary regimes produce distinct carbon and nitrogen isotope signatures and that (b) the isotope signature of the food source is incorporated into the consumer's tissues (e.g. Bender, 1971; Smith and Epstein, 1971; De Niro and Epstein, 1981; Kelly, 2000). Stable isotope compositions from mammal feces (Sponheimer et al., 2003; Hwang et al., 2007), such as bat guano, have been shown to reliably reflect diet (Herrera et al., 2001a,b; Painter et al., 2009; Soto-Centeno et al., 2014). For example, Wurster et al. (2007) have demonstrated the guano of insectivorous bats to record local vegetation and climate giving a strong relationship between $\delta^{13} \mathrm{C}$ values, the local abundance of dominant plant functional types (plants $\mathrm{C} 3, \mathrm{C} 4$ and $\mathrm{CAM}$ ) and insects that feed on local vegetation, which therefore reflect local environmental conditions. These plant functional types are associated with different carbon isotope signatures due to distinct photosynthesic fractionation, with $\delta^{13} \mathrm{C}$ values of $\mathrm{C} 3$ and $\mathrm{C} 4$ plants ranging from to -32 to $-20 \%$ and -15 to $-9 \%$, respectively (Bender, 1971; Smith and Epstein, 1971). Moreover, plants exhibiting C3 and $\mathrm{C} 4$ photosynthesis respond differently to ambient light conditions, temperature, $\mathrm{pCO}_{2}$ and humidity (e.g. Smith et al., 1976; Farquhar et al., 1989; Ehleringer et al., 1997). Local vegetation also varies seasonally, especially in tropical areas, where strong seasonal variations (dry and wet periods) are largely controlled by rainfall. These seasonal variations should produce important changes in stable isotope ratios from feces of phytophagous bats, a likelihood that up until now has not been thoroughly explored.

In fact, guano of phytophagous bats has received little attention despite the presence of significant deposits in several Neotropical areas, such as the Guadeloupe in the Lesser Antilles, which potentially represent unique sources of Pleistocene and Holocene paleoenvironmental data (Lenoble et al., 2009; Bochaton et al., 2015). The present paper aims to investigate the $\delta^{13} \mathrm{C}$ and $\delta^{15} \mathrm{~N}$ values of phytophagous bat guano collected regularly over a one-year period from two roosting sites in Guadeloupe in order to document seasonal variations and their amplitude, as well as correlate with climatic factors. Finally, we discuss the implications of these results for paleoenvironmental reconstructions.

\section{Materials and methods}

\subsection{Study areas}

The study was carried out on the island of Guadeloupe (Lesser Antilles, Caribbean), which has a tropical climate, primarily influenced by the seasonal changes in the Bermuda-Azores High and the Intertropical Convergence Zone (ITCZ) (Portecop, 1982). The island is characterized by a marked seasonality with (1) a dry period extending from December to May, where monthly mean temperatures are close to $25^{\circ} \mathrm{C}$ and monthly mean amounts of precipitation range between 50 and $200 \mathrm{~mm}$, and (2) a wet period, extending from July to November, where monthly mean temperatures reach $27-28{ }^{\circ} \mathrm{C}$ and then progressively decrease. The island receives the most rainfall during September and October, with an average of more than $200 \mathrm{~mm}$ per month (Lassere, 1961). Relative humidity remains high throughout the year and fluctuates a little, a trait typical of sub-equatorial climates. Easterly trade winds, which are less intense during the dry period, regulate climate conditions and attenuate high temperatures. The two halves of Guadeloupe, Basse-Terre and Grande-Terre, are characterized by distinct geographical and topographical contexts (Fig. 1), producing two different climates (Portecop, 1982; Rousteau et al., 1996) (Fig. 2). The relatively flat Grand-Terre is directly exposed to an easterly wind that affects surface water availability and thus favors the expansion of the deciduous dry forests. On the other hand, trade winds 
blow across the more mountainous Basse-Terre leading to greater rainfall and the development of seasonal evergreen tropical forest or rainforest at higher elevation (Fig. 1).

The bat guano analyzed in this study was collected from two roosting sites, each located at a different end of Guadeloupe (Fig. 1):

- The disused stable of "Ecurie Sainte-Marthe" (ESM) $\left(16^{\circ} 15.893^{\prime} \mathrm{N}, 61^{\circ} 16.171^{\prime} \mathrm{O}\right)$ on Grande-Terre, the eastern-half of Guadeloupe, in a suburban area surrounded by deciduous dry forest of the Saint François commune.

- "Grosse Montagne" Factory (GM Factory) $\left(16^{\circ} 13.918^{\prime} \mathrm{N}, 61^{\circ} 39.324^{\prime} \mathrm{O}\right)$ is an old sugar factory that has been abandoned for several decades. Located in a rural area of Basse-Terre, the western half of Guadeloupe, the GM Factory is surrounded by sugar cane crops and a moist tropical forest, forming a transition between the xerophytic Grande-Terre vegetation and the rainforest of the Basse-Terre uplands.
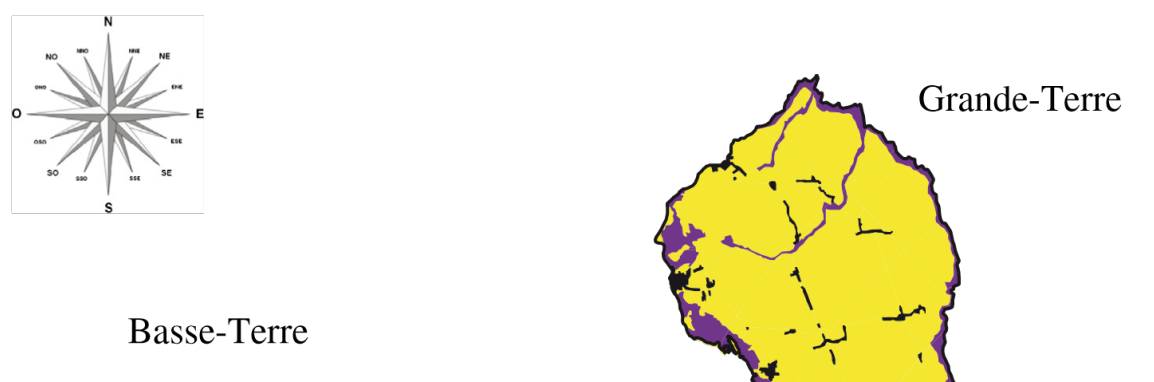

\section{Basse-Terre}

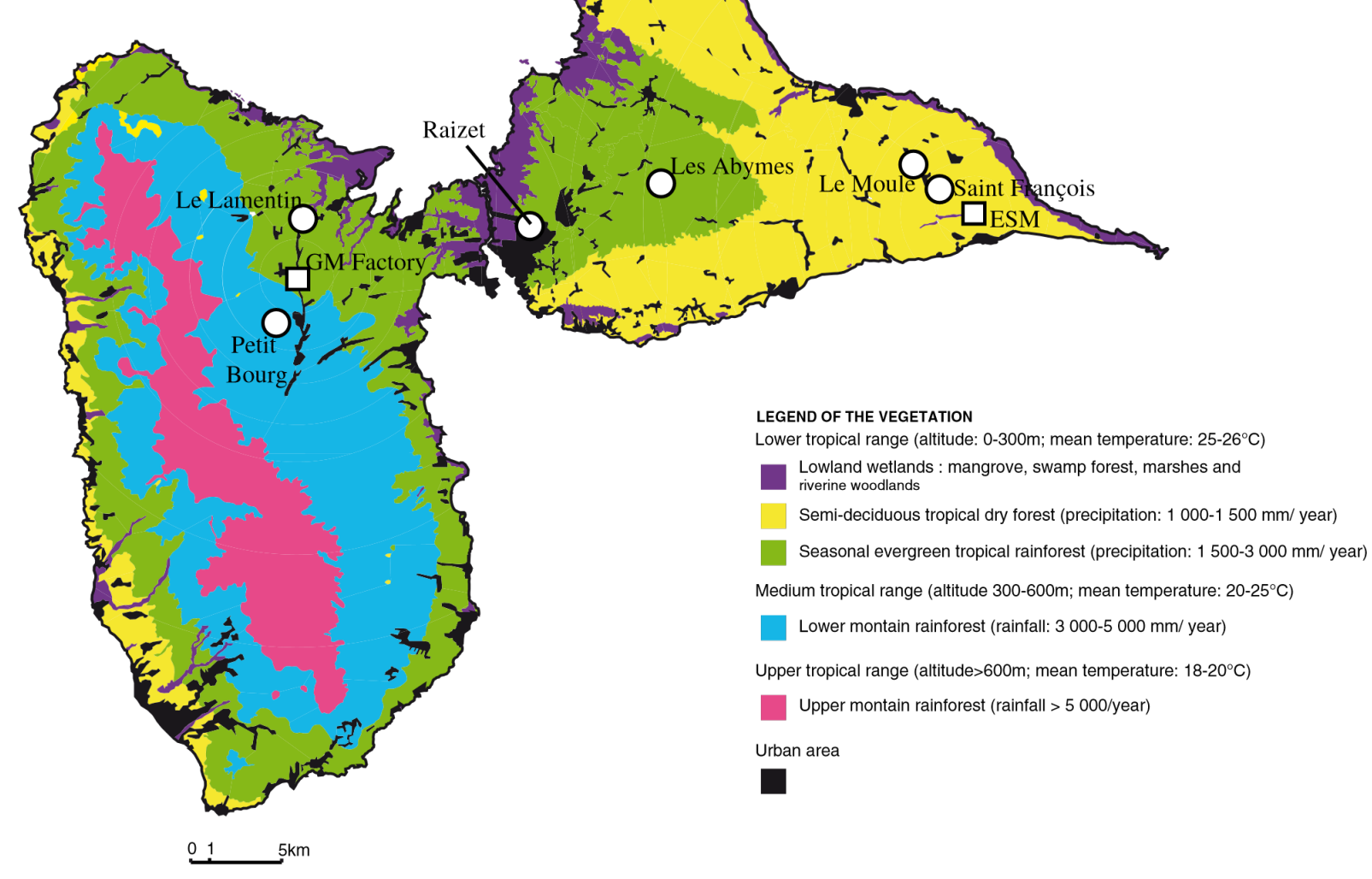

Fig. 1. Location of both sites (squares) Ecurie Sainte-Marthe (ESM) and Grosse Montagne Factory (GM Factory), as well as the location of the Mété-France weather stations (circles) on the vegetation map of the Guadeloupe (Lesser Antilles, Caribbean, France). Modified after Rousteau et al. (1996) and Sastre et al. (2007). 


\section{A) Weather station of "Le Moule"}

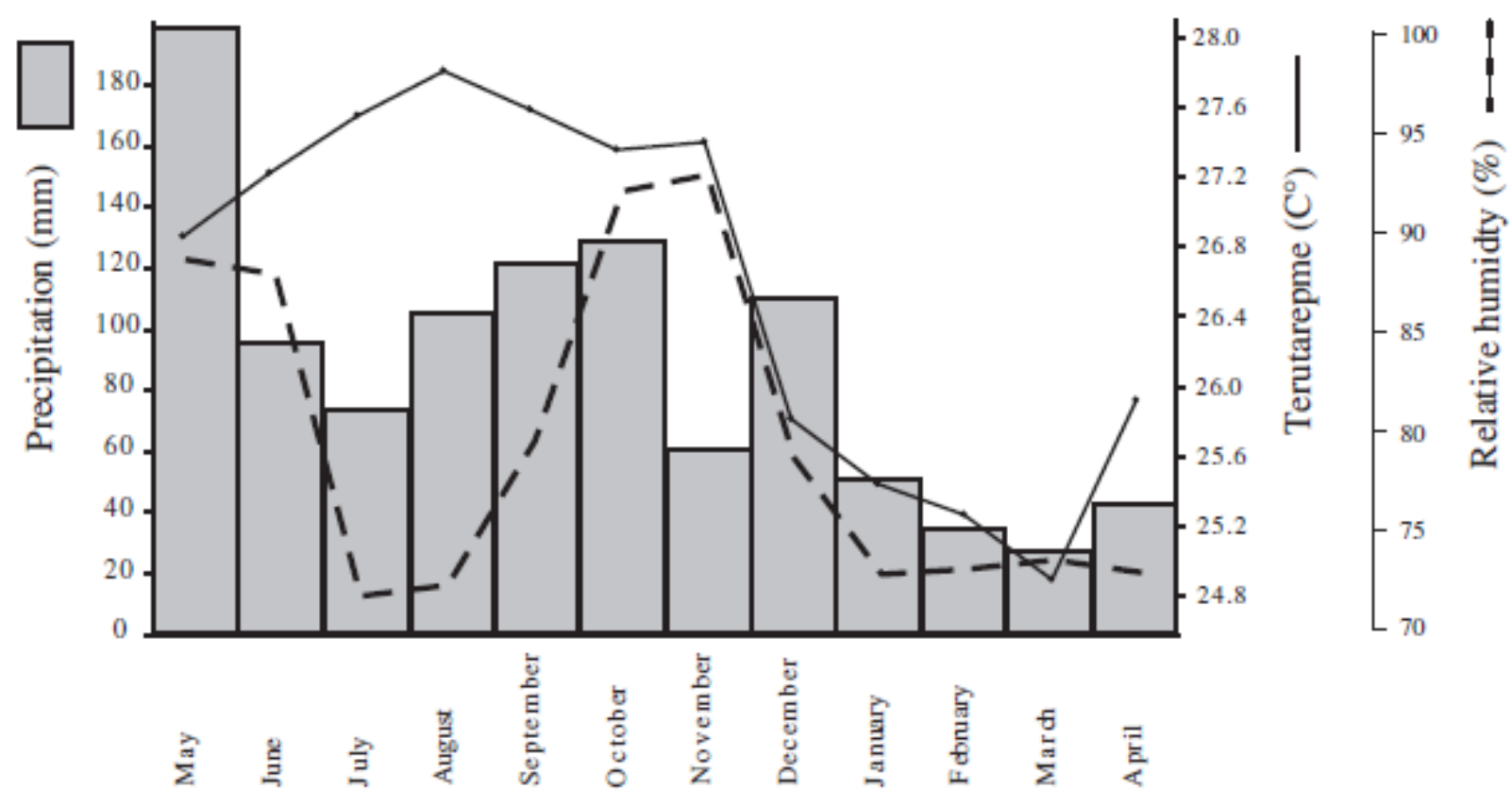

B) Weather stations of "Le Lamentin" and "Petit Bourg"

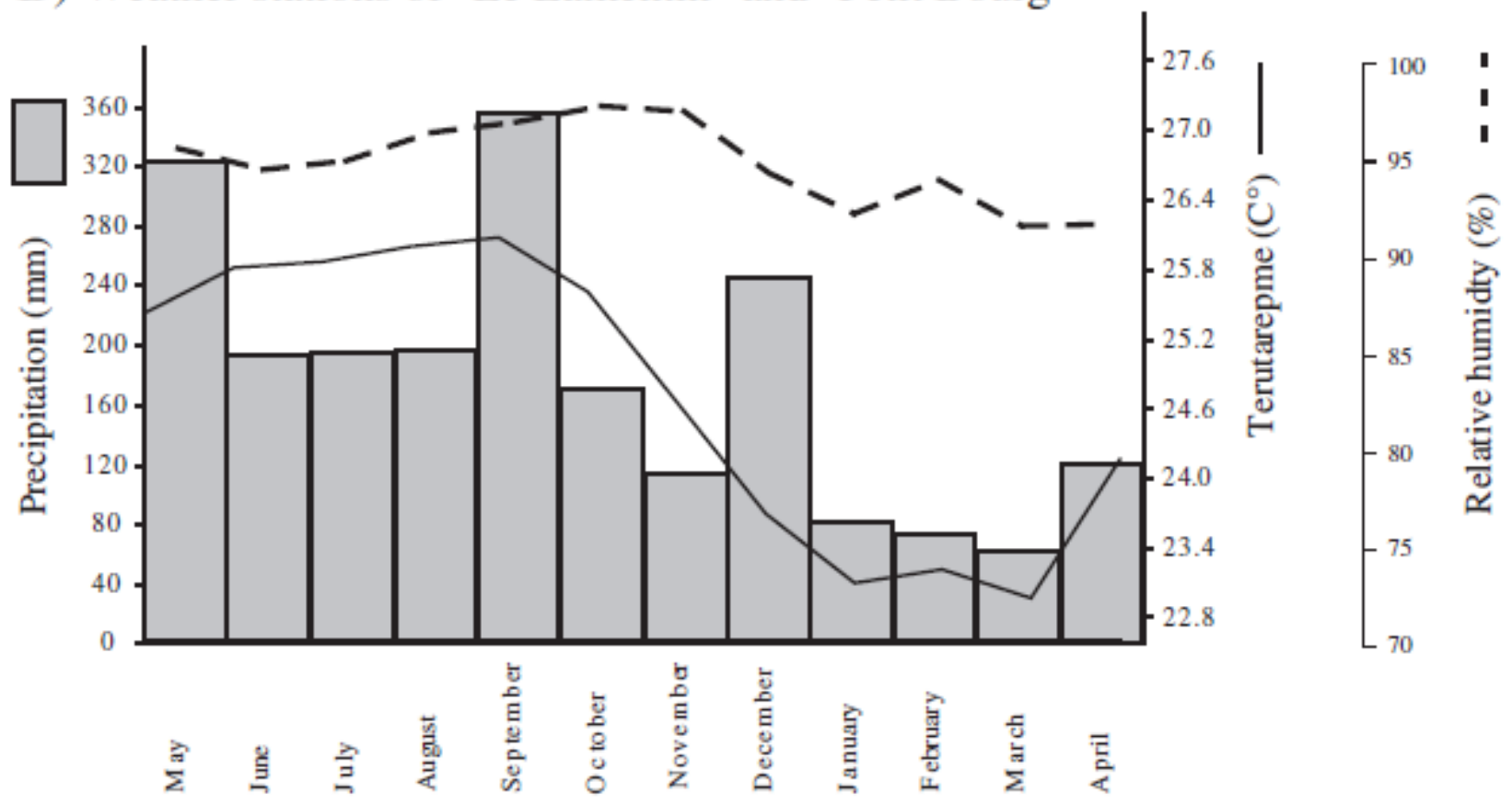

Fig. 2. Monthly temperatures variations $\left({ }^{\circ} \mathrm{C}\right)$, precipitation $(\mathrm{mm})$ and relative humidity (\%) between May 2013 and April 2014 for A) the "Le Moule" weather station on Grande-Terre close to Ecurie Sainte-Marthe (ESM), and B) the mean from the two weather stations of "Le Lamentin" and "Petit Bourg" located on Basse-Terre near the Grosse Montagne Factory (GM 


\subsection{Bat colonies}

The ESM bat colony consists of around 200 Jamaican fruit-eating bats (Artibeus jamaicensis), a member of the Phyllostomidae family. This phytophagous bat consumes mainly fruits with a large range of taxa, complemented by nectar and pollen, and very occasionally insects (Ortega and Castro-Arellano, 2001). While A. jamaicensis is capable of flying over distances of 10 to $12 \mathrm{~km}$ during periods when food is less abundant (Carstens et al., 2004), its usual feeding area remains on the scale of several square kilometers (Ortega and Castro-Arellano, 2001).

The GM Factory is home to one of the largest colonies of Antillean fruit-eating bats (Brachyphylla cavernarum) in Guadeloupe, numbering at least five thousands of individuals. This species is widely distributed in the Antillean Islands, extending from the Barbados in the south to Puerto Rico in the north. Compared to A. jamaicensis, B. cavernarum is known both to forage over larger areas distances, at times reaching up to $22 \mathrm{~km}$ (Carstens et al., 2004; Pedersen et al., 2006) and to have a more flexible diet, being able to complete fruit consumption by nectar and insects in variable proportion to adapt to local food resources (Bond and Seaman, 1958; Nellis, 1971; Nellis and Ehle, 1977; Swanepoel and Genoways, 1983; Pedersen et al., 1996; Soto-Centeno et al., 2001; Gannon, 2005; Picard and Catzeflis, 2013). The diet of B. cavernarum has also been shown to vary seasonally at the GM Factory, with the consumption of insects increasing significantly at the beginning of the dry season during both December and January (Lenoble et al., 2014).

\subsection{Sampling method}

Guano samples from both locations were collected on the same day at the beginning of each month during a one-year period between May 2013 and May 2014. An approximately $1 \mathrm{~m}^{2}$ resistant plastic film was placed below the daytime perch and replaced after each visit. Samples were dried soon after collection in order to avoid any modification (e.g. rotting), labeled and stored in a dried place before being sent to the laboratory.

A total of thirty-six carbon and nitrogen isotope values of bat guano were measured. The twelve's first correspond to one sample per month collected from ESM. The next twelve isotopic ratios correspond to one sample per month coming from the GM Factory. These twenty-four samples correspond to pools of guano. The last twelve isotopic ratios were corresponded to one sample per month collected from the GM Factory and were measured only from the vegetal component of the bat guano.

\subsection{Stable isotope procedures}

Each $0.5-2.0 \mathrm{mg}$ sample was sealed in a tin capsule and analyzed using an IRMS isotope ratio mass spectrometer (IsoPrime GV Instruments ${ }^{\circledR}$ ) interfaced with an Elemental Analyzer (EA; Flash2000, ThermoFisher ${ }^{\circledR}$ ) at the EPOC Laboratory (University of Bordeaux, France). IRMS daily drift was monitored using prepared standards (acetanilide, casein, glycin). Stable isotope ratios are expressed in the conventional delta notation as parts per thousand (\%) deviations from the international standards VPDB for $\delta^{13} \mathrm{C}$ and atmospheric $\mathrm{N}_{2}$ for $\delta^{15} \mathrm{~N}$. Duplicate measurements were performed for each sample. The standard deviation was equal to or better than $0.2 \%$ for $\delta^{15} \mathrm{~N}, 0.2 \%$ for nitrogen content, $0.3 \%$ o for $\delta^{13} \mathrm{C}$ and $2.0 \%$ for carbon content.

\subsection{Meteorological data and statistical analysis}

Stable isotope compositions were correlated against monthly mean temperatures, precipitation and relative humidity recorded between May 2013 and May 2014 by six Météo-France weather stations at 
different distances from the two sites (Fig. 1). T-test (t) and F-test (F) were used for inter-sample comparisons whereas correlations between climate parameters and isotope compositions were tested using the Spearman rank correlation coefficient (Rho).

\subsection{Insect remains}

Guano samples consist of amorphous black masses containing excreted fruit pulp (Bond and Seaman, 1958; Picard and Catzeflis, 2013) and insect fragments. At the PACEA laboratory of the University of Bordeaux, plant and insect remains were categorized and weighed as detailed in Lenoble et al. (2014).

\section{Results}

\subsection{Guano stable isotope compositions of ESM and GM factory}

Carbon isotope compositions of guano $\left(\delta^{13} \mathrm{C}\right)$ range from $-28.9 \%$ o to $-23.3 \%$ (Table 1$)$, with nearly identical mean $\delta^{13} \mathrm{C}$ value for both ESM $(-27.3 \pm 0.5 \%$ o $)$ and GM Factory $(-27.4 \pm 1.7 \%$ o, $\mathrm{t}=0.32 ; \mathrm{p}=$ $0.77 ; \mathrm{n}=24$ ). However, variances between the two sites differ significantly (variance for ESM $=0.3$; variance for GM Factory $=3.0 ; \mathrm{F}=11.28 ; \mathrm{p}=0.0003 ; \mathrm{n}=24$ ), with the GM Factory samples being more variable, which is partially due to the December and January values $(\mathrm{F}=1.03 ; \mathrm{p}=0.95 ; \mathrm{n}=22$ with the exclusion of the two months of December and January). These two months excluded, mean values differ significantly between guano samples from GM and ESM $(t=3.91 ; p=0.0009 ; n=22)$, with the GM Factory mean $\delta^{13} \mathrm{C}$ being $0.9 \%$ lower compared to the mean $\delta^{13} \mathrm{C}$ values of ESM. There is no covariation between monthly ESM and GM Factory $\delta^{13} \mathrm{C}$ values (Rho $\left.=0.03 ; \mathrm{p}=0.92 ; \mathrm{n}=24\right)$.

The nitrogen isotope compositions of guano $\left(\delta^{15} \mathrm{~N}\right)$ range between $8.6 \%$ and $10.6 \%$, and between 4.6 and $8.6 \%$, respectively, for samples coming from ESM and GM Factory, with an average difference of $3.3 \%$ between the sites (Table 1$)(t=8.23 ; \mathrm{p} \mathrm{b} 0.00001 ; \mathrm{n}=24)$. GM Factory samples present a higher variability $(\mathrm{SD}=1.34)$ compared to those from $\mathrm{ESM}$ samples $(\mathrm{SD}=0.67)(\mathrm{F}=3.34 ; \mathrm{p}=0.056 ; \mathrm{n}=24)$. Unlike the carbon isotope ratios, the higher variability of GM Factory samples results mainly from the two months of October and November (Table 1). By excluding these two months, GM Factory and ESM present a similar variance $(\mathrm{F}=1.32 ; \mathrm{p}=0.68 ; \mathrm{n}=22)$. There is no co-variation between monthly ESM and GM Factory $\delta^{15} \mathrm{~N}$ values $(\mathrm{Rho}=0.14 ; \mathrm{p}=0.65 ; \mathrm{n}=24)$.

\begin{tabular}{|c|c|c|c|c|c|c|c|c|c|c|}
\hline \multirow[t]{2}{*}{ Month of collect } & \multicolumn{5}{|c|}{ Ecurie Sainte-Marthe } & \multicolumn{5}{|c|}{ Grosse Montagne Factory } \\
\hline & $\% \mathrm{~N}$ & $\delta^{15} \mathrm{~N}(\%$ V-PDB $)$ & \%C & $\delta^{13} \mathrm{C}(\%$ V-PDB $)$ & $\overline{C: N \text { ratio }}$ & $\% \mathrm{~N}$ & $\delta^{15} \mathrm{~N}(\%$ V-PDB $)$ & \%C & $\delta^{13} \mathrm{C}(\%$ V-PDB $)$ & $\mathrm{C}: \mathrm{N}$ ratio \\
\hline May-13 & 2.0 & 8.7 & 47.1 & -26.7 & 23.1 & 2.8 & 6.6 & 43.0 & -28.6 & 15.5 \\
\hline June-13 & 1.3 & 9.7 & 42.1 & -27.1 & 31.9 & 5.4 & 6.3 & 43.3 & -28.4 & 8.1 \\
\hline July-13 & 1.4 & 8.6 & 42.3 & -27.8 & 29.4 & 5.3 & 5.3 & 42.1 & -28.3 & 8.1 \\
\hline August-13 & 1.8 & 8.9 & 42.0 & -27.9 & 22.7 & 5.8 & 4.6 & 45.7 & -28.1 & 7.9 \\
\hline September-13 & 2.4 & 9.7 & 44.1 & -27.9 & 18.2 & 5.5 & 5.9 & 42.8 & -28.3 & 8.0 \\
\hline October-13 & 2.2 & 9.6 & 44.1 & -27.3 & 19.8 & 5.7 & 83 & 44.8 & -28.4 & 7.9 \\
\hline November- 13 & 2.9 & 10.7 & 41.5 & -27.4 & 14.2 & 4.9 & 8.6 & 45.1 & -28.9 & 9.2 \\
\hline December-13 & 2.4 & 9.9 & 42.5 & -27.1 & 17.8 & 7.3 & 5.7 & 42.5 & -24.5 & 6.0 \\
\hline January-14 & 2.9 & 10.4 & 43.5 & -27.4 & 15.2 & 6.9 & 5.6 & 39.3 & -23.3 & 6.3 \\
\hline February-14 & 2.8 & 9.9 & 43.2 & -27.3 & 15.8 & 4.5 & 5.4 & 35.3 & -27.6 & 9.6 \\
\hline March-14 & 2.2 & 9.6 & 46.2 & -27.4 & 22.4 & 5.5 & 52 & 40.3 & -27.3 & 7.6 \\
\hline April-14 & 2.1 & 8.8 & 42.1 & -26.1 & 20.8 & 5.2 & 7.0 & 45.2 & -27.5 & 8.5 \\
\hline
\end{tabular}

Table 1. Carbon and nitrogen isotope compositions as well as the percentage of carbon and nitrogen of bulk bat guanos recovered from both sites (Ecurie Sainte-Marthe and Grosse Montagne Factory), by the month of collection.

The percentage values of nitrogen content $(\% \mathrm{~N})$ from ESM range from 1.3 to 2.9, with a mean of 2.2, whereas GM Factory has a larger range from 2.8 to 7.3 and a higher mean of 5.4 (Table 1) $(t=-8.89 ; \mathrm{p}$ b $0.00001 ; \mathrm{n}=24)$. There are no evident correlations between the ESM and GM Factory variations of nitrogen content $(\mathrm{Rho}=0.10 ; \mathrm{p}=0.74 ; \mathrm{n}=24)$. The percentage of carbon content $(\% \mathrm{C})$ from ESM and 
GM Factory present no differences (Table 1$)$, with identical means $(\mathrm{t}=0.95 ; \mathrm{p}=0.037 ; \mathrm{n}=24)$ and a distinct trend toward significance in terms of variance $(F=2.96 ; p=0.08 ; n=24)$.

The $\mathrm{C}: \mathrm{N}$ ratios from ESM range between 14.2 and 31.9 with a mean of 20.3. On contrary, GM Factory samples present a smaller range (from 6 to 15.5) and a distinct lower mean of 8.5 (Table 1). The monthly GM Factory C:N ratio is correlated with the difference between $\delta^{13} \mathrm{C}$ values of the bulk samples and ${ }^{13} \mathrm{C}$ values of the vegetal parts $\left(\Delta^{13} \mathrm{C}\right.$ bulk/vegetal - Table 4$)(R h o=0.64 ; \mathrm{p}=0.02 ; \mathrm{n}=24)$.

\subsection{Intra-site variations of guano $\delta^{13} \mathrm{C}$ and $\delta^{15} \mathrm{~N}$ values and correlations with climate} data

$\delta^{13} \mathrm{C}$ and $\delta^{15} \mathrm{~N}$ values of guano collected at ESM site do not co-vary $(\mathrm{Rho}=-0.09 ; \mathrm{p}=0.79 ; \mathrm{n}=24)$ (Fig. 3), and no consistent co-variation is observable between isotope composition and precipitation and relative humidity recorded at the weather stations (Table 2). Significant relationships are nevertheless evident between $\delta^{13} \mathrm{C}$ values and temperatures from the two meteorological stations of Le Moule and Raizet (Table 2).

\begin{tabular}{|c|c|c|c|c|c|c|}
\hline \multirow[t]{2}{*}{ Weather station } & & \multirow[t]{2}{*}{ Parameter } & \multicolumn{2}{|l|}{$\delta^{13} \mathrm{C}: \mathrm{ESM}$} & \multicolumn{2}{|l|}{$\delta^{15} \mathrm{~N}:$ ESM } \\
\hline & & & Rho spearman & $\overline{p \text {-value }}$ & Rho spearman & p-value \\
\hline Saint François & Precipitation & Mean month P 2013-14 & -0.20 & 0.51 & -0.37 & 0.23 \\
\hline Le Moule & Precipitation & Mean month P 2013-14 & -0.08 & 0.80 & -0.17 & 0.59 \\
\hline Les Abymes & Precipitation & Mean month P 2013-14 & -0.41 & 0.18 & -0.22 & 0.50 \\
\hline Raizet & Precipitation & Mean month P 2013-14 & -0.40 & 0.67 & -0.11 & 0.73 \\
\hline Lamentin & Precipitation & Mean month P 2013-14 & -0.22 & 0.50 & -0.39 & 0.21 \\
\hline Petit bourg & Precipitation & Mean month P 2013-14 & 0.26 & 0.42 & -0.18 & 0.56 \\
\hline Raizet & Temperature & Mean month T 2013-14 & -0.57 & 0.05 & -0.47 & 0.12 \\
\hline Petit bourg & Temperature & Mean month T 2013-14 & -0.51 & 0.08 & 0.10 & 0.74 \\
\hline Le Moule & Temperature & Mean month T 2013-14 & -0.69 & 0.01 & -0.28 & 0.38 \\
\hline Le Moule & Relative Humidity & Mean month HUM Rel 2013-14 & 0.23 & 0.47 & 0.32 & 0.31 \\
\hline Petit bourg & Relative Humidity & mean month HUM Rel 2013-14 & -0.57 & 0.05 & -0.06 & 0.87 \\
\hline Raizet & Relative Humidity & Mean month HUM Rel 2013-14 & -0.55 & 0.07 & 0.05 & 0.88 \\
\hline
\end{tabular}

Table 2 Correlations between climate variables and stable isotope values of bat guano samples from Ecurie Sainte-Marthe.

In GM Factory, co-variations are observable between $\delta^{13} \mathrm{C}$ and temperatures from Le Rayzet, Le Moule and Petit Bourg, which is this closest weather station (Table 3). Co-variations are also observed between $\delta^{13} \mathrm{C}$ and relative humidity from the Le Rayzet and Petit Bourg weather stations (Table 3). $\delta^{15} \mathrm{~N}$ values from GM Factory guano samples co-vary only with the relative humidity measured at Le Moule (Table 3). Comparing guano samples from GM Factory and ESM, no co-variations in $\delta^{13} \mathrm{C}$ and $\delta^{15} \mathrm{~N}$ (Fig. 3), or between isotope composition and precipitation.

\begin{tabular}{|c|c|c|c|c|c|c|}
\hline \multirow[t]{2}{*}{ Weather station } & & \multirow[t]{2}{*}{ Parameter } & \multicolumn{2}{|c|}{$\delta^{13} \mathrm{C}$ : GM Factory } & \multicolumn{2}{|c|}{$\delta^{15} \mathrm{~N}$ : GM Factory } \\
\hline & & & Rho spearman & p-value & Rho spearman & $\mathrm{p}$-value \\
\hline Saint François & Precipitation & Mean month P 2013-14 & -0.30 & 0.34 & -0.27 & 0.40 \\
\hline Le Moule & Precipitation & Mean month P 2013-14 & -0.44 & 0.15 & 0.24 & 0.46 \\
\hline Les Abymes & Precipitation & Mean month P 2013-14 & -0.28 & 0.39 & -0.18 & 0.57 \\
\hline Raizet & Precipitation & Mean month P 2013-14 & -0.23 & 0.47 & -0.15 & 0.63 \\
\hline Lamentin & Precipitation & Mean month P 2013-14 & -0.23 & 0.46 & -0.17 & 0.60 \\
\hline Petit bourg & Precipitation & Mean month P 2013-14 & -0.48 & 0.12 & 0.14 & 0.67 \\
\hline Raizet & Temperature & Mean month T 2013-14 & -0.56 & 0.05 & -0.08 & 0.80 \\
\hline Petit bourg & Temperature & Mean month T 2013-14 & -0.59 & 0.05 & -0.27 & 0.40 \\
\hline Le Moule & Temperature & mean month T 2013-14 & -0.58 & 0.05 & -0.06 & 0.85 \\
\hline Le Moule & Relative Humidity & Mean month HUM Rel 2013-14 & -0.67 & 0.02 & 0.67 & 0.02 \\
\hline Petit bourg & Relative Humidity & Mean month HUM Rel 2013-14 & -0.78 & 0.00 & 0.28 & 0.38 \\
\hline Raizet & Relative Humidity & Mean month HUM Rel 2013-14 & -0.04 & 0.91 & -0.32 & 0.15 \\
\hline
\end{tabular}

Table 3 Correlations between climate variables and stable isotope values of bat guano samples from Grosse Montage Factory. 

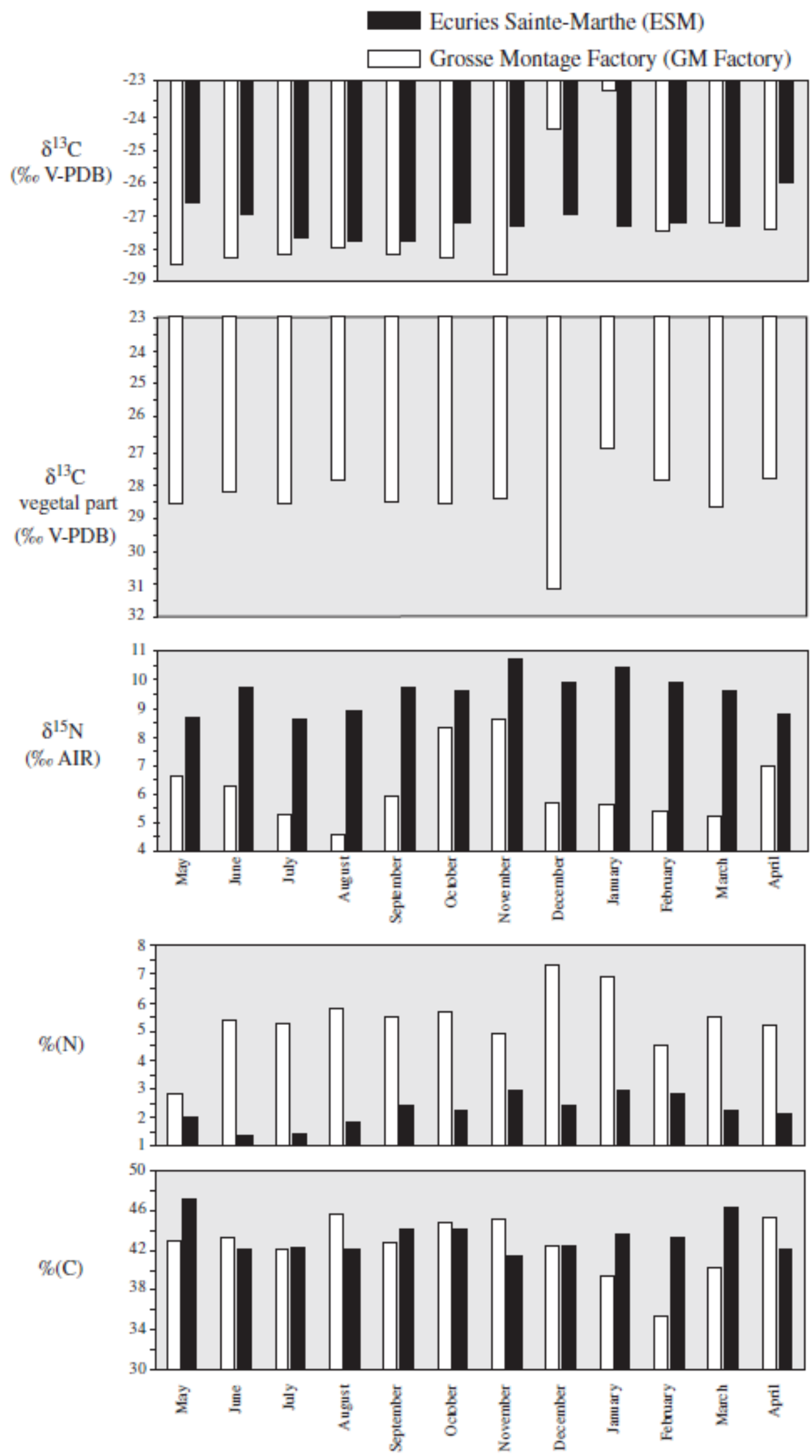

Fig. 3.Monthly values of carbon and nitrogen isotope compositions of bat guano from Ecurie Sainte-Marthe and from GM Factory, from the months of May 2013 to April 2014, as well as the percentage of carbon and nitrogen content. 


\section{Insect consumption and carbon isotope compositions from vegetal part}

No insect remains were present in the ESM samples, whereas significant quantities were recorded in the GM Factory samples. Carbon isotope compositions from the vegetal part of GM Factory have a mean value close to $-28.5 \pm 0.3$, with values ranging from -27 to $-31.2 \%$. The two months of December and January present the larger differences of 3.7 and $6.6 \%$, respectively, with the carbon isotope composition of bulk samples (Table 4). No significant differences have been observed between carbon isotope compositions of bulk and vegetal part samples from GM Factory $(\mathrm{t}=1.91 ; \mathrm{p}=0.07 ; \mathrm{n}=24)$. Furthermore, no significant co-variations were identified between isotope compositions from GM Factory and percentage of insect consumption ( $R h o=-0.40 ; p=0.20 ; n=24)$ (Table 4). Finally, mean values differ significantly between guano samples from the vegetal part of GM Factory and ESM ( $\mathrm{t}=$ $3.70 ; \mathrm{p}=0.0007 ; \mathrm{n}=24$ ), with the GM Factory mean $\delta^{13} \mathrm{C}$ of the vegetal part being $1.25 \%$ o lower compared to the mean $\delta^{13} \mathrm{C}$ values of ESM.

\begin{tabular}{llll}
\hline \multirow{2}{*}{$\begin{array}{l}\text { Month of } \\
\text { collection }\end{array}$} & \multicolumn{3}{l}{ Grosse Montagne Factory } \\
\cline { 2 - 4 } & $\begin{array}{l}\delta^{13} \mathrm{C} \text { vegetable part } \\
(\% \text { V-PDB })\end{array}$ & $\begin{array}{l}\Delta^{13} \mathrm{C} \text { bulk/vegetal } \\
(\% \text { V-PDB })\end{array}$ & $\begin{array}{l}\text { Proportion of } \\
\text { vegetal mass }(\%)\end{array}$ \\
\hline May-13 & -28.7 & 0.0 & 81.9 \\
June-13 & -28.3 & 0.2 & 75.2 \\
July-13 & -28.7 & -0.4 & 82.3 \\
August-13 & -28.0 & 0.0 & 96.7 \\
September-13 & -28.6 & -0.3 & 89.6 \\
October-13 & -28.7 & -0.3 & 84.2 \\
November-13 & -28.5 & 0.4 & 70.6 \\
December-13 & -31.2 & -6.6 & 45.9 \\
January-14 & -27.0 & -3.7 & 48.8 \\
February-14 & -28.0 & -0.3 & 71.5 \\
March-14 & -28.8 & -1.5 & 76.2 \\
April-14 & -27.9 & -0.4 & 72.8 \\
\hline
\end{tabular}

Table 4 Carbon isotope compositions measured on the vegetable component of guano samples from Grosse Montagne Factory, as well as the proportion of vegetal mass by month of collection.

\section{Discussion}

\subsection{Isotope fractionation between diet and feces}

Stable isotope compositions from feces, such as bat guano, reflect the dietary sources of the animal (Wurster et al., 2007; Painter et al., 2009; Salgado et al., 2014), whereas an isotopic fractionation observable between feces production and bat diet $\left(\Delta_{\text {diet-feces }}\right)$ depends on species

Table 3

and their physiological characteristics (Hwang et al., 2007). For example, Painter et al. (2009) suggest that, unlike the fermented plant material in the gut of herbivorous species, the digesta of insectivorous bats may not undergo radical changes in the gastrointestinal tract. For insectivorous bats, the $\Delta_{\text {diet-feces }}$ in $\delta^{13} \mathrm{C}$ values were measured from $-0.11 \pm 0.8 \%$ (Salvarina et al., 2013) to 0.8\%o (Des Marais et al., 1980). Insectivorous bats also present a $\Delta_{\text {diet-feces }}$ of $1.47 \pm 1.5 \%$ for $\delta^{15} \mathrm{~N}$ (Salvarina et al., 2013). Furthermore, Salvarina et al. (2013) have demonstrated that stable isotopes from insectivorous bat guano reflect the most recently consumed food sources. 
While the exact factors underlying differences between diet and feces of phytophagous bats are still unknown like insectivorous bats, the digestive system of Neotropical fruit bats is short, with the swallowed juice being transited in half an hour or less (Morrison, 1980) and seeds are excreted intact for phytophageous bats such as A. jamaicensis or B. cavernarum (Bond and Seaman, 1958; Picard and Catzeflis, 2013). The guano of bats is thus different compared to feces produced by other mammals, being both not fermented and less digested, and consequently, the $\Delta_{\text {diet-feces }}$ is probably close to zero. Therefore a close match between diet and feces isotopic values is expected. $\delta^{13} \mathrm{C}$ values observed at ESM and GM Factory range between -23.3 and $-28.9 \%$ and thus reflect a diet mainly based on C3 plants.

\subsection{Stable isotope compositions, climate and environment}

Bat guano samples from GM Factory present significant differences in $\delta^{13} \mathrm{C}$ (when December and January values are excluded), $\delta^{15} \mathrm{~N}$, or $\% \mathrm{~N}$ values compared to those obtained for the ESM. These two sites are located in two areas of Guadeloupe that differ markedly in climate conditions and vegetation. Several previous studies have suggested that drier climate conditions induce higher carbon and nitrogen isotope compositions in both plants and mammals (e.g. Murphy and Bowman, 2006, 2009; Kohn, 2010). The higher mean $\delta^{13} \mathrm{C}$ and $\delta^{15} \mathrm{~N}$ values observed from ESM are in good agreement with drier local weather conditions. Additionally, a difference is still observed in the mean values between $\delta^{13} \mathrm{C}$ values from ESM and $\delta^{13} \mathrm{C}$ values measured from the vegetal parts of the GM Factory that had probably a more similar in the chemical makeup rather than the bulk samples of GM Factory. Consequently, annual differences in climate conditions between these two sites located at opposites ends of Guadeloupe are clearly reflected in stable isotope compositions from feces.

Important seasonal rainfall variations in Guadeloupe produce substantially different vegetation patterns that likely impacted the diet of phytophagous bats (Herrera et al., 2008), such as A. jamaicensis, which preferentially consumes ripe fruits that are abundant during the beginning of the wet season. Carbon and nitrogen isotope compositions of guano from ESM and GM Factory depict intra-sites variations during the year-long study period such as in ESM with amplitude in $\delta^{13} \mathrm{C}$ variations reaching up to $1.8 \%$. However, as observed in both Wurster et al. (2007) and Sullivan et al. (2006) analyses feces from insectivorous bats, no correlations were observed between rainfall and stable isotope compositions from feces of phytophagous bats. The lack of co-variation with this important climate variable reflects that lack of a simple relationship between precipitation, vegetation and bat feces. Isotope compositions from bat feces are not a direct proxy of paleoprecipitation. However, co-variations were observed between $\delta^{13} \mathrm{C}$ values from both ESM and GM Factory feces and temperature variations recorded at the closest weather station. It is also worth recalling that the diet of phytophagous bats generally comprised large quantity of fruits requiring at least several weeks to ripen. Moreover, during the same night bats may consume different fruits with varying maturation rates and growing under slightly different climate conditions. Consequently, climate information recorded by food consumed by bats represents a timeaveraged signal reflecting climate processes lasting several weeks or months. In the Caribbean, while temperature is not a major factor controlling climatic conditions, like relative humidity, it varies seasonally (Lassere, 1961). Correlations between these two variables suggest that carbon isotope compositions of guano reflect seasonal changes in local vegetation, which reflect the foraging ranges of bats (from 5 to $20 \mathrm{~km}$ ). 


\subsection{A diet representative of the local environment? Impact of diet variations}

Seasonal variations can strongly impact mammals such as bats, at times leading them to migrate in order to secure food (Fleming et al., 1993) or to seasonally adapt and expand their diet to include complementary food sources (Zortéa, 2003; Barros et al., 2013). The two sites of ESM and GM Factory are home to different phytophagous bat species with distinct diets. Feces samples from ESM have no insect component while those from the GM Factory contain variable and sometimes high quantities of insects (Table 4). Numerous studies have demonstrated that at the same location, bats feeding on animal tissues (insects, small vertebrates, and blood) present higher $\delta^{15} \mathrm{~N}$ and $\delta^{13} \mathrm{C}$ values than those feeding uniquely on plant (fruit, nectar) (Herrera et al., 2001a,b; Schondube et al., 2001; Soto-Centeno et al., 2014). This pattern is mainly due to trophic enrichment as well as high nitrogen content $(\% \mathrm{~N})$. However, guano samples from the GM Factory present lower $\delta^{13} \mathrm{C}$ and $\delta{ }^{15} \mathrm{~N}$ values than the ESM but are at the same time characterized by higher percentages of nitrogen content $(\% \mathrm{~N})$, attesting to a complementary input of insect protein (Studier et al., 1994; Pearson et al., 2003; Emerson and Roark, 2007). Consequently, the difference in mean $\delta{ }^{15} \mathrm{~N}$ values between ESM and GM Factory despite the consumption of insects in the case of bats from GM Factory hence confirms these two sites have distinct baseline vegetation values related to their different climate conditions. Insects recovered from GM Factory guano samples are mainly comprise the genus Phyllophaga Harris, 1826 (Lenoble et al., 2014) which are known to preferentially consume sugar cane (Chalumeau, 1983), a C4 plant commonly cultivated around the site. This may explain the high $\delta^{13} \mathrm{C}$ values during periods when $\mathrm{B}$. cavernarum diet included a high percentage of insects. As well, the incorporation of insects in the B. cavernarum diet enriches also the carbon isotope composition of their feces. This suggests that if B. cavernarum had not consumed insects, the $\delta^{13} \mathrm{C}$ values would have been lower than the actual ones and hence would have reflected a more important difference of environmental condition between ESM and GM Factory than the one observed. The proportion of insect remains in GM Factory feces is estimated to be lower than $20 \%$, except for the months of December and January, where insect can reach as high as $54 \%$ of the guano mass (Table 4). Samples from GM Factory also present the highest $\% \mathrm{~N}$ and $\delta^{13} \mathrm{C}$ values (bulk analyses) during these two months, but decrease significantly whenonly the vegetal component of feces is analyzed (Table 4). Moreover, samples of these two months present also the lower C:N ratios. December and January correspond to the beginning of the dry period, when relatively few plants are flowering and limited quantities of fruits are available. The diet of B. cavernarum at the GM Factory therefore appears to have been heavily influenced by seasonal variations in food resources (Lenoble et al., 2014). The extension of the foraging spectrum to include insects would therefore underlie the 5.6\%o isotopic variation.

The dry forest environment of Grande-Terre should produce more important variations of carbon isotope compositions in the ESM samples compared to those from the GM Factory associated with wetter local weather conditions. As predicted, $\delta{ }^{13} \mathrm{C}$ variation evident in the ESM samples fits well with the strong alternating dry and wet season, whereas no cyclic seasonal pattern is observed in $\delta^{13} \mathrm{C}$ signal from GM Factory (Fig. 3). In order to directly compare stable isotope variations in guano of the mainly frugivorous bats from GM Factory and ESM feces, the samples from December and January were firstly excluded, as B. cavernarum from GM expanded its diet to include a large proportion of insects, and secondly carbon isotope compositions measured only from the vegetable part of feces recovered from GM Factory were considered. When December and January values are excluded, carbon isotope compositions from GM Factory present similar amplitude of variations and variances $\left(\Delta_{\max \text {-min }} \delta^{13} \mathrm{C}=\right.$ $1.6 \%$, ) to those from $\operatorname{ESM}\left(\Delta_{\max -\min } \delta^{13} \mathrm{C}=1.8 \%\right.$ ), demonstrating seasonal changes to impact both dry and moist areas on the same order of isotopic variations. When only the vegetal fraction from the GM 
Factory samples is considered, a higher amplitude of variations $\left(\Delta_{\max -\min } \delta^{13} \mathrm{C}=4.2 \%\right.$ o $)$ can be observed compared to those obtained for ESM, which can be connected to the lowest values recorded for the month of December. When the December sample from the vegetal part is excluded, carbon isotope compositions from ESM and GM Factory present similar amplitudes of variations. Finally, this lack of contrasting $\delta^{13} \mathrm{C}$ variations in ESM samples can be explained by three factors: 1) the small size of ESM colony, which can helps to mitigate the over-consumption of local resources and allows $\mathrm{A}$. jamaicensis to take advantage of the rare available fruits and flowers even in the dry season, 2) the location of the roosting site in a suburban area that permits the bats to consume locally-available imported fruits with different flowering and ripening periods as well as irrigated orchards, such as the papaya, and 3) variations in foraging areas, which may increase the averaging of the isotopic signal when bats cover larger areas.

The combination of the above demonstrates seasonal changes of food eaten by frugivorous bats from Guadeloupe to underlie isotopic variability in feces. This variability can be related to 1) the modification of vegetation and the stable isotope compositions as is in the case with the ESM samples that evince carbon isotope composition changes lowers than $2 \%$, or 2 ) shifts in bat behavior, particular feeding habits, as suggested by GM Factory feces, which present $\delta^{13} \mathrm{C}$ amplitude values close to $5.6 \%$.

\subsection{Implications and limits for paleoenvironmental analysis}

This study shows that the stable isotope compositions from guano of phytophagous bats to record changes in the local vegetation. As such, they can be used as a reliable proxy for reconstructing past environmental conditions. However, this study illustrates the important role played by the ecology of bats that must be taken into account for paleorecord studies in order to minimize biases related to different ecological behaviors. In particular, the modification of phytophagous bat diets toward a consumption of insects can lead to sizable changes in isotopic compositions as observed in GM Factory samples. The $\mathrm{C}: \mathrm{N}$ ratios being correlated with the modification of the carbon isotope compositions from GM Factory, it can thus be used as an indicator of the diet modification. An alternative way, when a modification of diet is suspected, is to combine $\delta^{13} \mathrm{C}$ analyses of guano with molecular $\delta^{13} \mathrm{C}$ analyses of normal alkanes components (nalkanes), which constitute a major component of epicuticular waxes that are found on the leaves and stems of higher plants and which can be preserved in sub-fossil deposits (e. g. Wurster et al., 2010a).

Furthermore, our results show seasonal variations of vegetation to have influenced carbon isotope compositions of guano from ESM, with an amplitude of $1.8 \%$ and higher values obtained during the driest period. Variations in stable isotope compositions from fossil feces can as well be related with changes in the seasonal occupation of a roosting site. However, the order of magnitude in carbon isotope compositions related to seasonal changes is still lower than those observed in fossil feces samples. For example, Holocene levels from the Bat Cave of Grand Canyon (Arizona, USA) present differences of $\delta^{13} \mathrm{C}$ values from feces of insectivorous bats of up to $2.5 \%$ (Wurster et al., 2008), with those from Gaura cu Musca Cave (Romania) presenting differences of up to 2.9\%o (Onac et al., 2013). The PleistoceneHolocene transition levels from Jacksons Bay Cave (Jamaica) show differences of up to $11.1 \%$ (McFarlane et al., 2002), while those from Makangit Cave (Palawan) present differences of up to 16.1\%o (Bird et al., 2007). Therefore, even if seasonal variations produce changes in isotopic composition, they are insufficient to blur alterations in past vegetation connected to climatic variations. 


\section{Concluding remarks}

Here we investigated stable carbon and nitrogen isotope composition measured in fruit bat guano collected monthly during a one-year period. Stable isotope compositions from bat guano depend on the bat's foraging area of bats as well as their diet. This was shown to be the case for phytophagous bats that include a variety of fruits, flowers and nectars in their diet. This dietary variability serves to average climatic variations over intervals of several weeks. Consequently, stable isotope compositions from phytophagous bat guano vary as a function of both local environment and season. Seasonal variations can create isotopic variability either directly by modifying stable isotope compositions recorded by vegetation, or indirectly by forcing bats to change their feeding habits. In either case, the order of magnitude of these seasonal changes is smaller than that of past climate change.

Bat guano constitutes a valuable proxy for evaluating environmental changes that can be used to reconstruct paleoenvironments. The occurrence of cave deposits composed primarily of guano in tropical, semiarid and arid regions that generally region lack terrestrial records further reinforces the interest of fossil guano as a powerful data source for reconstructing terrestrial paleoenvironments.

\section{Acknowledgments}

This study was conducted as a part of the CNRS BIVAAG Program with support from a European PO-FEDER grant 2007-2013 no. 2/2.4/33456, the Guadeloupe Regional Council, the DEAL of Guadeloupe, and the DAC of Guadeloupe. The authors are grateful to "Météo-France" for making available data concerning weather conditions in Guadeloupe. The authors would also like to thank Daniel Imbert, Baptiste Angin, Philippe Martinez and JeanBernard Huchet for their help. The authors also acknowledge the insightful comments made by the three anonymous reviewers.

\section{References}

Barros, M.A.S., Rui, A.M., Fabian, M.E., 2013. Seasonal variation in the diet of the bat Anoura caudifer (Phyllostomidae: Glossophaginae) at the southern limit of its geographic range. Acta Chiropterol. 15, 77-84.

Bender, M.M., 1971. Variation in the ${ }^{13} \mathrm{C} /{ }^{12} \mathrm{C}$ ratios of plants in relation to the pathway of photosynthetic carbon dioxide fixation. Phytochemistry 10, 1234-1244.

Bertran, P., Bonnissent, D., Imbert, D., Lozouet, P., Serrand, N., Stouvenot, C., 2004. Paléoclimat des Petites Antilles depuis 4000 ans BP: l'enregistrement de la lagune de Grand-Case à Saint-Martin. C. R. Geosci. 336, 1501-1510.

Bird, M.I., Boobyer, E.M., Bryant, C., Lewis, H.A., Paz, V., Stephens, W.E., 2007. A long record of environmental change from bat guano deposits in Makangit Cave, Palawan, Philippines. Earth Environ. Sci. Trans. R. Soc. Edinb. 98, 59-69.

Bochaton, C., Grouard, S., Cornette, R., Ineich, I., Lenoble, A., Tresset, A., Bailon, S., 2015. Fossil and subfossil herpetofauna from Cadet 2 Cave (Marie-Galante, Guadeloupe Islands, FWI): evolution of an insular herpetofauna since the Late Pleistocene. C.R. Palevol 14, 101-110.

Bond, R.M., Seaman, G.A., 1958. Notes on a colony of Brachyphylla cavernarum. J. Mammal. 39, 150151.

Carrión, J.S., Scott, L., Marais, E., 2006. Environmental implications of pollen spectra in bat droppings from southeastern Spain and potential for palaeoenvironmental reconstructions. Rev. Palaeobot. Palynol. 140, 175-186.

Carstens, B.C., Sullivan, J., Davalos, L.M., Larsen, P.A., Pedersen, S.C., 2004. Exploring population genetic structure in three species of Lesser Antillean bats. Mol. Ecol. 13, 2557-2566. 
Chalumeau, F., 1983. Coléoptères Scarabaeides des Petites Antilles. Encyclopédie entomologique XLIV. Lechevalier, Paris (261 pp.).

Chase, B.M., Scott, L., Meadows, M.E., Gil-Romera, G., Boom, A., Carr, A.S., Reimer, P.J., Truc, L., Valsecchi, V., Quick, L.J., 2012. Rock hyrax middens: a palaeoenvironmental archive for southern African drylands. Quat. Sci. Rev. 56, 107-125.

De Niro, M.J., Epstein, S., 1981. Influence of diet on the distribution of nitrogen isotopes in animals. Geochim. Cosmochim. Acta 45, 341-351.

Des Marais, D.J., Mitchell, J.M., Meinschein, W.G., Hayes, J.M., 1980. The carbon isotope biogeochemistry of the individual hydrocarbons in bat guano and the ecology of the insectivorous bats in the region of Carlsbad, New Mexico. Geochim. Cosmochim. Acta 44, 2075-2086.

Ehleringer, J.R., Cerling, T.E., Helliker, B.R., 1997. C4 photosynthesis, atmospheric $\mathrm{CO}_{2}$, and climate. Oecologia 112, 285-299.

Emerson, J.K., Roark, A.M., 2007. Composition of guano produced by frugivorous, sanguivorous, and insectivorous bats. Acta Chiropterol. 9, 261-267.

Emery, K.F., Kennedy Thornton, E., 2008. A regional perspective on biotic change during the Classic Maya occupation using zooarchaeological isotopic chemistry. Quat. Int. 191, 131-143.

Farquhar, G.D., Ehleringer, J.R., Hubick, K.T., 1989. Carbon isotope discrimination and photosynthesis. Annu. Rev. Plant Biol. 40, 503-537.

Fensterer, C., Scholz, D., Hoffmann, D.L., Spötl, C., Schröder-Ritzrau, A., Horn, C., Pajón, J.M., Mangini, A., 2013. Millennial-scale climate variability during the last 12.5 ka recorded in a Caribbean speleothem. Earth Planet. Sci. Lett. 361, 143-151.

Fleming, T.H., Nuñez, R.A., Sternberg, L.d.S.L., 1993. Seasonal changes in the diets of migrant and non-migrant nectarivorous bats as revealed by carbon stable isotope analysis. Oecologia 94, 72-75.

Gannon, M.R., 2005. Bats of Puerto Rico: An Island Focus and a Caribbean Perspective. Texas Tech University Press.

Geantă, A., Tanţău, I., Tămaş, T., Johnston, V.E., 2012. Palaeoenvironmental information from the palynology of an 800 year old bat guano deposit from Măgurici Cave, NW Transylvania (Romania). Rev. Palaeobot. Palynol. 174, 57-66.

Herrera, L.G., Fleming, T.H., Findley, J.S., 1993. Geographic variation in carbon composition of the pallid bat, Antrozous pallidus, and its dietary implications. J. Mammal. 74, 601-606.

Herrera, L.G., Gerardo, L., Hobson, K.A., Manzo, A., Estrada, B., Sánchez-Cordero, V., Méndez, C., 2001a. The role of fruits and insects in the nutrition of frugivorous bats: evaluating the use of stable isotope models 1. Biotropica 33, 520-528.

Herrera, L.G., Hobson, K.A., N. RamÍrez, P., G. Méndez, C., Sánchez-Cordero, V., 2001b. Sources of protein in two species of phytophagous bats in a seasonal dry forest: evidence from stable-isotope analysis. J. Mammal. 82, 352-361.

Herrera, L.G., Korine, C., Fleming, T.H., Arad, Z., 2008. Dietary implications of intrapopulation variation in nitrogen isotope composition of an old world fruit bat. J. Mammal. 89, 1184-1190.

Hobson, K.A., 1999. Tracing origins and migration of wildlife using stable isotopes: a review. Oecologia 120, 314-326.

Hodell, D.A., Curtis, J.H., Jones, G.A., Higuera-Gundy, A., Brenner, M., Binford, M.W., Dorsey, K.T., 1991. Reconstruction of Caribbean climate change over the past 10, 500 years. Nature 352, 790-793.

Hodell, D.A., Anselmetti, F.S., Ariztegui, D., Brenner, M., Curtis, J.H., Gilli, A., Grzesik, D.A., Guilderson, T.J., Müller, A.D., Bush, M.B., 2008. An 85-ka record of climate change in lowland Central America. Quat. Sci. Rev. 27, 1152-1165. 
Hwang, Y.T., Millar, J.S., Longstaffe, F.J., 2007. Do $\delta^{15} \mathrm{~N}$ and $\delta^{13} \mathrm{C}$ values of feces reflect the isotopic composition of diets in small mammals? Can. J. Zool. 85, 388-396.

Kelly, J.F., 2000. Stable isotopes of carbon and nitrogen in the study of avian and mammalian trophic ecology. Can. J. Zool. 78, 1-27.

Kohn, M.J., 2010. Carbon isotope compositions of terrestrial C3 plants as indicators of (paleo)ecology and (paleo)climate. PNAS 107, 19691-19695.

Lachniet, M.S., Asmerom, Y., Burns, S.J., Patterson, W.P., Polyak, V.J., Seltzer, G.O., 2004. Tropical response to the $8200 \mathrm{yr}$ BP cold event? Speleothem isotopes indicate a weakened early Holocene monsoon in Costa Rica. Geology 32, 957-960.

Lachniet, M.S., Johnson, L., Asmerom, Y., Burns, S.J., Polyak, V., Patterson, W.P., Burt, L., Azouz, A., 2009. Late Quaternary moisture export across Central America and to Greenland: evidence for tropical rainfall variability from Costa Rican stalagmites. Quat. Sci. Rev. 28, 3348-3360.

Lassere, G., 1961. La Guadeloupe, étude géographique. Union française d'impression, Bordeaux.

Lenoble, A., Stouvenot, C., Courtaud, P., Grouard, S., Scalliet, M., Serrand, N., 2009. Formes et remplissages du karst littoral guadeloupéen. Le karst, indicateur performant des environnements passés et actuels ICN ed. pp. 226-233 (Vanara, N. et Douat, M., Orthez).

Lenoble, A., Angin, B., Huchet, J.-B., Royer, A., 2014. Seasonal insectivory of the Antillean fruit bat (Brachyphylla cavernarum). Caribb. J. Sci. 48 (2-3), 127-131.

Maher Jr., L.J., 2006. Environmental information from guano palynology of insectivorous bats of the central part of the United States of America. Palaeogeogr. Palaeoclimatol. Palaeoecol. 237, 19-31.

Malaizé, B., Bertran, P., Carbonel, P., Bonnissent, D., Charlier, K., Galop, D., Imbert, D., Serrand, N., Stouvenot, C., Pujol, C., 2011. Hurricanes and climate in the Caribbean during the past 3700 years BP. The Holocene 21, 911-924.

McFarlane, D.A., Lundberg, J., Fincham, A.G., 2002. A late Quaternary paleoecological record from caves of southern Jamaica, West Indies. J. Cave Karst Stud. 64, 117-125.

Mizutani, H., McFarlane, D.A., Kabaya, Y., 1992a. Carbon and nitrogen isotopic signatures of bat guanos as record of past environments. J. Mass Spectrom. Soc. Jpn. 40, 67-82.

Mizutani, H., McFarlane, D.A., Kabaya, Y., 1992b. Nitrogen and carbon isotope study of bat guano core from Eagle Creek Cave, Arizona, USA. J. Mass Spectrom. Soc. Jpn. 40, 57-65.

Morrison, D.W., 1980. Efficiency of food utilization by fruit bats. Oecologia 45, 270-273.

Murphy, B.P., Bowman, D.M.J.S., 2006. Kangaroo metabolism does not cause the relationship between bone collagen $\delta^{15} \mathrm{~N}$ and water availability. Funct. Ecol. 20, 1062-1069.

Murphy, B.P., Bowman, D.M.J.S., 2009. The carbon and nitrogen isotope composition of Australian grasses in relation to climate. Funct. Ecol. 23, 1040-1049.

Nellis, D.W., 1971. Additions to the natural History of Brachyphylla (chiroptera). Caribb. J. Sci. 11, 91.

Nellis, D.W., Ehle, C.P., 1977. Observations on the behavior of Brachyphylla cavernarum (Chiroptera) in Virgin Islands. Mammalia 41, 403-410.

Olson, S.L., 1982. Fossil vertebrates from the Bahamas. Smithson. Contrib. Paleobiol.

Onac, B.P., Forray, F.L., Wynn, J.G., Giurgiu, A.M., 2013. Guano-derived 813C-based paleohydroclimate record from Gaura cu Musca Cave, SW Romania. Environ. Earth Sci. 1-9. Ortega, J., Castro-Arellano, I., 2001. Artibeus jamaicensis. Mamm. Species 1-9.

Painter, M.L., Chambers, C.L., Siders, M., Doucett, R.R., Whitaker, J.J.O., Phillips, D.L., 2009. Diet of spotted bats (Euderma maculatum) in Arizona as indicated by fecal analysis and stable isotopes. Can. J. Zool. 87, 865-875. 
Pearson, S., Levey, D., Greenberg, C., Martínez del Rio, C., 2003. Effects of elemental composition on the incorporation of dietary nitrogen and carbon isotopic signatures in an omnivorous songbird. Oecologia 135, 516-523.

Pedersen, S.C., Genoways, H.H., Freeman, P.W., 1996. Notes on bats from Montserrat (Lesser Antilles) with comments concerning the effects of hurricane Hugo. Caribb. J. Sci. 32, 206-213.

Pedersen, S.C., Larsen, P.A., Genoways, H.H., Lindsay, K., Morton, M., Adams, R., Swier, V.J., Appino, J., 2006. Bats of Antigua, northern Lesser Antilles.

Picard, R., Catzeflis, F., 2013. Première étude des chauves-souris dans les goyaveraies de Martinique, Biodiversité insulaire: la flore, la faune et l'homme dans les Petites Antilles. Direction de l'Environnement. de l'Aménagement et du Logement de Martinique et Université des Antilles et de la Guyane, Fort-de-France, Martinique, pp. 174-183.

Popa-Lisseanu, A.G., Kramer-Schadt, S., Quetglas, J., Delgado-Huertas, A., Kelm, D.H., Ibáñez, C., 2015. Seasonal variation in stable carbon and nitrogen isotope values of bats reflect environmental baselines. PLoS One 10 (2), e0117052. http://dx.doi.org/ 10.1371/journal.pone.0117052.

Portecop, J., 1982. Végétation. Atals des Départements français d'Outre-Mer.III. La Guadeloupe. Centre national de la recherche scientifique, Paris.

Pregill, G.K., Olson, S.L., 1981. Zoogeography of West Indian vertebrates in relation to Pleistocene climatic cycles. Annu. Rev. Ecol. Syst. 12, 75-98.

Rousteau, A., Portecop, J., Rollet, B., 1996. Carte écologique de la Guadeloupe. ONF, UAG, PNG, CGG, Jarry, Guadeloupe.

Salgado, S.S., Motta, P.C., Souza Aguiar, L.M., Nardoto, G.B., 2014. Tracking dietary habits of cave arthropods associated with deposits of hematophagous bat guano: a study from a neotropical savanna. Austral Ecol. 39, 560-566.

Salvarina, I., Yohannes, E., Siemers, B.M., Koselj, K., 2013. Advantages of using fecal samples for stable isotope analysis in bats: evidence from a triple isotopic experiment. Rapid Commun. Mass Spectrom. 27, 1945-1953.

Sastre, C., Breuil, A., Bernard, J.F., Feldmann, P., Fournet, J., 2007. Plantes, milieux et paysages des Antilles françaises: écologie, biologie, identification, protection et usages. Biotope.

Schondube, J.E., Herrera, L.G., Martínez del Rio, C., 2001. Diet and the evolution of digestion and renal function in phyllostomid bats. Zoology 104, 59-73.

Smith, B.N., Epstein, S., 1971. Two categories of ${ }^{13} \mathrm{C} /{ }^{12} \mathrm{C}$ ratios for higher plants. Plant Physiol. 47, 380384.

Smith, B.N., Oliver, J., Mc Millan, C., 1976. Influence of carbon source, oxygen concentration, light intensity, and temperature on ${ }^{13} \mathrm{C} /{ }^{12} \mathrm{C}$ ratios in plant tissues. Bot. Gaz. 137, 99-104.

Soto-Centeno, J.A., Rodriguez-Durán, A., Cortes, E., 2001. Erophylla sezekorni and Brachyphylla cavernarum diet of two Phyllostomid bats in Puerto Rico. Bat. Res. News 42, 180-181.

Soto-Centeno, J.A., Phillips, D.L., Kurta, A., Hobson, K.A., 2014. Food resource partitioning in syntopic nectarivorous bats on Puerto Rico. J. Trop. Ecol. 30, 1-11.

Sponheimer, M., Robinson, T., Ayliffe, L., Roeder, B., Hammer, J., Passey, B., West, A., Cerling, T., Dearing, D., Ehleringer, J., 2003. Nitrogen isotopes in mammalian herbivores: hair $\delta^{15} \mathrm{~N}$ values from a controlled feeding study. Int. J. Osteoarchaeol. 13, 80-87.

Stansell, N.D., Abbott, M.B., Rull, V., Rodbell, D.T., Bezada, M., Montoya, E., 2010. Abrupt Younger Dryas cooling in the northern tropics recorded in lake sediments from the Venezuelan Andes. Earth Planet. Sci. Lett. 293, 154-163.

Studier, E.H., Sevick, S.H., Ridley, D.M., Wilson, D.E., 1994. Mineral and nitrogen concentrations in feces of some Neotropical bats. J. Mammal. 674-680. 
Sullivan, J.C., Buscetta, K.J., Michener, R.H., Whitaker, J.O., Finnerty, J.R., Kunz, T.H., 2006. Models developed from $\delta^{13} \mathrm{C}$ and $\delta^{15} \mathrm{~N}$ of skin tissue indicate non-specific habitat use by the big brown bat (Eptesicus fuscus). Ecoscience 13, 11-22.

Swanepoel, P., Genoways, H.H., 1983. Brachyphylla cavernarum. Mamm. Species 1-6.

Wurster, C.M., McFarlane, D.A., Bird, M.I., 2007. Spatial and temporal expression of vegetation and atmospheric variability from stable carbon and nitrogen isotope analysis of bat guano in the southern United States. Geochim. Cosmochim. Acta 71, 3302-3310.

Wurster, C.M., Patterson, W.P., McFarlane, D.A., Wassenaar, L.I., Hobson, K.A., Athfield, N.B., Bird, M.I., 2008. Stable carbon and hydrogen isotopes from bat guano in the Grand Canyon, USA, reveal Younger Dryas and 8.2 ka events. Geology 36, 683-686.

Wurster, C.M., Bird, M.I., Bull, I.D., Creed, F., Bryant, C., Dungait, J.A.J., Paz, V., 2010a. Forest contraction in north equatorial Southeast Asia during the Last Glacial Period. PNAS 107, 1550815511.

Wurster, C.M., McFarlane, D.A., Bird, M.I., Ascough, P., Athfield, N.B., 2010b. Stable isotopes of subfossil bat guano as a long-term environmental archive: insights from a Grand Canyon cave deposit. J. Cave Karst Stud. 72, 111-121.

Zortéa, M., 2003. Reproductive patterns and feeding habits of three nectarivorous bats (Phyllostomidae: Glossophaginae) from the Brazilian Cerrado. Braz. J. Biol. 63, 159-168. 